house officers of the Children's Hospital of Philadelphia for providing excellent care of these patients: Joseph Egler for technical assistance: and Susan Anderson for helping with the manuscript. We also thank Dr. Camillus Witzleban for providing the information on liver histology: Dr. Stanton Segal for his advice: Dr. Albert Winegrad for many helpful discussions: and the Surgical Department of the Children's Hospital for their help in obtaining biopsies.

34. Requests for reprints should be addressed to: Charles A. Stanley, M. D., Div. of Endocrinology/Diabetes, Children's Hospital of Philadelphia, 34th and
Civic Center Blvd.. Philadelphia, PA. 19104.

35. This work was supported in part by National Institutes of Health grants $A M$ 15120, GM 25494, RR 00240, NS 17752, AM 07314, HD 07107. HD 08536 GM 07511, a grant from the Juvenile Diabetes Foundation and the Medical Associates Research and Education Foundation of the Children's Hospital. This work was presented in part at the May 1982 meeting of the Society for Pediatric Research.

36. Received for publication October 1,1982

37. Accepted for publication March 17, 1983

\title{
The Proportion of Mitochondrial Isoenzyme of Aspartate Aminotransferase Is Not Elevated in Reye's Syndrome
}

\author{
DONALD M. MOCK, ${ }^{(34)}$ MARION SCOTT, NELL I. MOCK, AND M. MICHAEL THALER \\ Division of Pediatric Gastroenterology and Nutrition, Department of Pediatrics, and the General Clinical \\ Research Center, University of California, San Francisco, California USA
}

\begin{abstract}
Summary
We reexamined a previously reported, highly specific increase in the relative proportion of the mitochondrial isoenzyme of asparate aminotransferase (AST) in the serum of patients with Reye's Syndrome. Using ion exchange chromatography, we measured mitochondrial, cytosolic, and total AST in serum samples from (1) 10 patients early in the course of Reye's Syndrome; (2) nine controls with normal serum AST; and (3) seven controls with other diseases causing an increase in serum AST. The mitochondrial percentage $(2.8 \pm 2.0 \%)$ in Reye's Syndrome was significantly lower $(P<0.05)$ than that of both the normal control group $(6.1 \pm 7.1 \%)$ and the group with increased AST $(5.6 \pm 4.0 \%)$. We thus failed to confirm the previous report of a specific increase in the \% of mitochondrial isoenzyme in Reye's Syndrome, and conclude that the $\%$ of mitochondrial isoenzyme is not likely to be a useful marker of (or predictor for progression to) Reye's Syndrome.
\end{abstract}

\section{Abbreviations}

AST, aspartate aminotransferase

$\mathrm{LDH}$, lactate dehydrogenase

MDH, malate dehydrogenase

P-5-P, pyridoxal-5'-phosphate

Aspartate aminotransferase (EC 2.6.1.1, formerly SGOT) consists of distinct cytoplasmic and mitochondrial isoenzymes in most mammalian species including man $(2,6,11,18,19)$. In normal individuals, the $\%$ of total serum AST activity due to the mitochondrial isoenzyme has been reported to be less than $10 \%$ by investigators using the most precise techniques $(19,20)$. The $\%$ of mitochondrial serum AST generally remains relatively constant in liver diseases associated with hepatocellular damage, such as acute and chronic viral hepatitis, fulminant hepatitis, chronic active hepatitis, and cirrhosis $(7,9,13,27)$, but can be elevated acutely in response to hepatotoxins.
A rapid increase in the total serum concentration of AST occurs consistently in Reye's Syndrome (encephalopathy with fatty visceral degeneration), a grave complication of common childhood viral infections such as chicken pox and influenza $A$ and B (5). Swelling and pleomorphism of liver cell mitochondria occur early in the course of Reye's Syndrome and recede within days after onset $(1,15)$. The temporal pattern of these mitochondrial changes and the absence of other remarkable alterations in hepatocellular ultrastructure suggested the possibility that the early rise and rapid decline in serum AST in Reye's syndrome reflected release of isoenzyme from swollen mitochondria. Indeed, a previous report had detected such a rise in the mitochondrial isoenzyme (32). Because the mortality and morbidity of Reye's Syndrome can be reduced by early institution of control of intracranial pressure (28), a marker predicting which patients with influenza or varicella will progress to Reye's Syndrome would be of considerable clinical utility and could yield important information about onset, evolution, and pathogenesis of the syndrome. We sought to confirm and extend the previous observation in a group of well characterized patients with Reye's Syndrome. We applied highly accurate techniques for chromatographic separation and measurement of AST isoenzymes in 10 children with Reye's Syndrome, in seven children with other disorders causing an increase in serum AST, and in nine control subjects with normal serum AST. The \% of mitochondrial isoenzyme was not elevated in any of the Reye's Syndrome patients.

\section{MATERIALS AND METHODS}

Assay of total AST activity. We used an enzyme-coupled spectrophotometric method for measurement of total AST activity in both serum samples and column eluates.

AST catalyzes the transfer of an amino group from aspartate to 2-oxoglutarate:

$$
\text { 2-oxoglutarate }+ \text { aspartate } \rightarrow \text { glutamate }+ \text { oxalacetate }
$$

In this assay the production of oxalacetate was coupled to oxi- 
dation of NADH (Boehringer Mannheim) by the malate dehydrogenase (Sigma) reaction:

$$
\text { oxalacetate }+\mathrm{NADH}+\mathrm{H}^{+} \rightarrow \text { malate }+\mathrm{NAD}^{+}
$$

NADH oxidation was measured spectrophotometrically at 340 $\mathrm{nm}$. Final reagent concentrations were as follows: 2-oxoglutarate, $13 \mathrm{mM}$; aspartate, $240 \mathrm{mM}$; MDH, $200 \mathrm{U} /$ liter; NADH, 0.19 $\mathrm{mM}$; P-5'-P, $0.10 \mathrm{mM}$; lactate dehydrogenase, $65 \mathrm{U} /$ liter; Trisma buffer, $80 \mathrm{mM}$. These concentrations were essentially the same as those recommended by the International Federation of Clinical Chemistry for an "optimized" AST assay (14) with the following modification: we used lower concentrations of $\mathrm{MDH}$ and LDH (Sigma) because we found that the MDH and LDH had small amounts of contaminating AST activity. This "background" AST activity was minimized by using the smallest concentration of MDH that catalyzed maximal activity for sample concentrations up to $100 \mathrm{U} /$ liter at $30^{\circ} \mathrm{C}$. Samples with activity $>100 \mathrm{U} /$ liter were diluted to $<100 \mathrm{U} /$ liter.

P-5-P (Boehringer-Mannheim), the cofactor for both AST isoenzymes, was added in order to measure total enzyme activity, including any apoenzyme either originally present in the patient's serum or produced by loss of coenzyme during chromatography. Rej et al. (21) has shown that omission of P-5-P can cause a significant underestimation of AST activity in some cases. A 10min preincubation with $\mathrm{LDH}$ was performed to avoid a pyruvatedependent background reaction (16) and to allow P-5-P to bind (22). The reaction was initiated by the addition of 2-oxoglutarate. The rate of change of absorbance at $340 \mathrm{~nm}$ was measured initially in a thermostat-controlled Aminco DW2 spectrophotometer using a $1.5 \mathrm{~nm}$ band width and $\Delta \epsilon_{340}=6.22 \times 10^{3} \mathrm{M}^{-1}$ $\mathrm{cm}^{-1}$ for NADH. Later experiments were performed on a Centrifichem spectrophotometer, calibrated relative to the DW2 (4). All reaction rates are expressed in $\mathrm{U}(\mu \mathrm{mole} / \mathrm{min})$ at $30^{\circ} \mathrm{C}$.

For sample activities ranging from $1-150 \mathrm{U} /$ liter, the reaction was linear with the amount of sample and with time up to 30 min, and was saturated with respect to 2-oxoglutarate, aspartate, NADH, MDH, LDH, and P-5-P. Measured values were calculated as the mean of 10 reaction velocities determined over 2min intervals; values for both normal and elevated enzyme standards (Precipath/norm Enzyme Standards, Boehringer Mannheim) were consistently within the stated range. To correct for small amounts of AST contamination, aspartate-free blanks and reagent blanks were routinely performed and blank activities subtracted appropriately (4).

The precautions detailed above allow measurement of AST activity $( \pm 5 \%)$ in a given sample of $\geq 1 \mathrm{U} /$ liter at $30^{\circ} \mathrm{C}$. This value was taken as the lower detection limit of the assay. For sample activities $<1 \mathrm{U} /$ liter (e.g., some column eluates), samples were either concentrated or increased as a $\%$ of the final reaction mixture to produce measured reaction rates $>10 \mathrm{U} /$ liter. Both maneuvers gave the same result.

Chromatographic separation of isoenzymes. To determine the activity of the mitochondrial and cytosolic isoenzymes in a serum sample, we separated the isoenzymes by column chromatography using DEAE-Sephadex-A50 (Pharmacia), a resin with both molecular sieving and ion exchange properties. Previous studies had been criticized for prolonged dialysis before chromatography, which might lead to selective loss of mitochondrial activity (9). For the conditions utilized in this study, we determined that prior dialysis was not necessary, and dialysis was omitted. A volume of between $0.1-0.5 \mathrm{ml}$ of serum was loaded onto a $6 \mathrm{x}$ $82 \mathrm{~mm}$ column previously equilibrated in $50 \mathrm{mM}$ Tris-Cl, 50 $\mathrm{mM} \mathrm{NaCl} \mathrm{pH}$ 8.5. The cationic (anodal) cytosolic isoenzyme (pI 5.0) binds to the positively charged quaternary amino groups of the DEAE-A50 resin; the anionic (cathodal) mitochondrial isoenzyme (pI 10.3) does not bind and was washed off the column with at least $4 \mathrm{ml}$ of $25 \mathrm{mM}$ Tris, $25 \mathrm{mM} \mathrm{NaCl}$ buffer $\mathrm{pH}=8.5$. The cytosolic enzyme was then eluted with $8 \mathrm{ml}$ of $240 \mathrm{mM}$ $\mathrm{NaCl}, 25 \mathrm{mM}$ Tris $\mathrm{pH}$ 8.5. The column wash and the eluate were collected in 1-ml fractions; AST activity was measured in each fraction. A typical elution pattern is shown in Figure 1.

Verification of the method. We next verified that this chromatographic method indeed resulted in a clean separation of isoenzymes with complete recovery.

We first prepared mitochondrial isoenzyme free of cytosolic isoenzyme by sonication of a mitochondrial fraction obtained by centrifugation of homogenized human or rat liver (17), and we prepared cytosolic isoenzyme free of mitochondrial isoenzyme from human or rat erythrocytes by osmotic shock followed by centrifugal sedimentation of the membrane fragments (23).

We verified that the chromatographic separation was complete for the uncontaminated isoenzymes from rat and man, both when chromatographed separately and when mixed together in either the low salt buffer, "normal" serum, or serum from a Reye's Syndrome patient. Separated isoenzymes rechromatographed as single fractions. Recovery of total activity was $101 \pm$ $7 \%(\bar{x} \pm$ S.D.); recovery of isoenzyme was complete when either was added to serum from either Reye's Syndrome patients or normals.

The chromatographic conditions described above are essentially the same as those arrived at empirically and independently by Sampson, et al. (26).

\section{STUDY GROUPS}

Patients with Reye's Syndrome. Ten patients were available for study (Table 1): four had chicken pox, five had an influenzalike illness, and one (the youngest patient) had malaise and poor feeding before the onset of intractable vomiting. The diagnosis

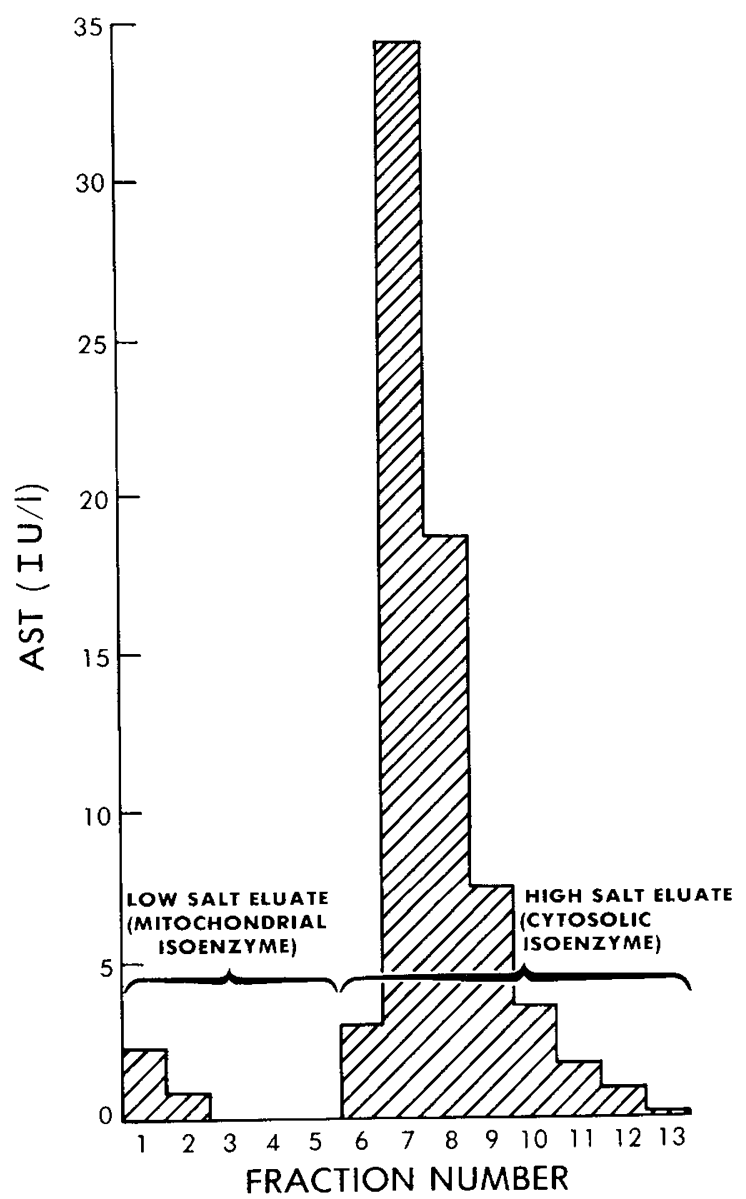

Fig. 1. A typical elution profile for chromatographic separation of aspartate aminotransferase (AST) isoenzymes. Sample volume, $0.30 \mathrm{ml}$ of serum from patient \#5 (total AST $=267 \mathrm{U} /$ liter); volume of low salt wash, $5.0 \mathrm{ml}$ : and volume of high salt eluate, $8.0 \mathrm{ml}$. 
Table 1. Clinical data and isoenzyme ratios from patients with Reye's syndrome ${ }^{1}$

\begin{tabular}{|c|c|c|c|c|c|c|c|c|c|c|}
\hline $\begin{array}{c}\text { Patient } \\
\text { No. }\end{array}$ & \multicolumn{2}{|l|}{$\begin{array}{l}\text { Age, } \\
\text { sex }\end{array}$} & $\begin{array}{c}\text { Prodromal } \\
\text { illness }\end{array}$ & $\begin{array}{r}\text { Stage } \\
\text { on adm. }\end{array}$ & $\begin{array}{c}\text { Deepest } \\
\text { stage }\end{array}$ & Outcome & $\begin{array}{c}\text { Total AST } \\
\text { (U/liter) }\end{array}$ & $\% \mathrm{M}$ & $\% \mathrm{C}$ & $\mathrm{M} / \mathrm{C}$ ratio \\
\hline 1 & $7 \mathrm{mo}$ & $\mathrm{M}$ & $\mathrm{N}$ & II & III & $\begin{array}{c}\text { Neurologic } \\
\text { sequelae }\end{array}$ & 78 & 7.5 & 92.5 & 0.081 \\
\hline 2 & $6 \mathrm{yr}$ & $\mathrm{F}$ & V & II & II & Normal & $\begin{array}{c}147 \\
(145)\end{array}$ & $\begin{array}{c}2.1 \\
(2.3)\end{array}$ & $\begin{array}{c}97.9 \\
(97.7)\end{array}$ & $\begin{array}{c}0.021 \\
(0.024)\end{array}$ \\
\hline 3 & $7 \mathrm{mo}$ & $F$ & I & III & IV & $\begin{array}{c}\text { Neurologic } \\
\text { sequelae }\end{array}$ & 224 & 3.3 & 96.7 & 0.034 \\
\hline 4 & $3 \mathrm{yr}$ & $\mathrm{M}$ & I & I & I & Normal & 247 & 2.1 & 97.9 & 0.021 \\
\hline 5 & $7 \mathrm{yr}$ & $\mathrm{F}$ & I & II & III & Normal & 267 & 4.3 & 95.7 & 0.045 \\
\hline 6 & $4 \mathrm{yr}$ & $\mathrm{F}$ & V & II & II & Normal & 349 & 1.8 & 98.2 & 0.081 \\
\hline 7 & $7 \mathrm{yr}$ & $F$ & V & III & IV & Normal & 984 & 3.7 & 96.3 & 0.039 \\
\hline 8 & $6 \mathrm{yr}$ & $\mathrm{F}$ & I & II & IV & Normal & 990 & 0.5 & 99.5 & 0.005 \\
\hline 9 & $13 \mathrm{yr}$ & $\mathrm{F}$ & I & II & II & Normal & 1016 & 1.9 & 98.1 & 0.019 \\
\hline 10 & $4 \mathrm{yr}$ & $\mathrm{F}$ & V & III & V & Death & 2414 & 1.3 & 98.7 & 0.013 \\
\hline Mean + & & & & & & & $(294)$ & $\underline{(0.7)}$ & $(99.3)$ & $(0.007)$ \\
\hline inean \pm & & & & & & & $6 \overline{70 \pm 717}$ & $2.8 \pm 2.0$ & $97.2 \pm 2.0$ & $0.029 \pm 0.021$ \\
\hline
\end{tabular}

${ }^{1}$ Definitions: M, male; F, female; V, varicella; I, influenza-like illness with fever; N, non-specific prodromal illness; ( ), denotes a sequential determination, see text; and AST, aspartate aminotransferase.

Table 2. Isoenzyme ratios in control groups

\begin{tabular}{|c|c|c|c|c|c|}
\hline & $\begin{array}{c}\text { Total AST } \\
(\mathrm{U} / \text { liter })\end{array}$ & $\begin{array}{c}\text { AST }^{1} \text { levels }(n \\
\% \mathrm{M} \\
\end{array}$ & $\% \mathrm{C}$ & \multicolumn{2}{|c|}{ M/C Ratio } \\
\hline Mean \pm S.D. & $24.5 \pm 10.6$ & $6.7 \pm 6.6$ & $93.9 \pm 7.2$ & & 0.068 \\
\hline Patient No. & Diagnosis & $\begin{array}{c}\text { eased AST leve } \\
\text { Total AST } \\
\text { (U/liter) }\end{array}$ & $\% \mathrm{M}$ & $\% \mathrm{C}$ & M/C Ratio \\
\hline $\begin{array}{l}1 \\
2\end{array}$ & $\begin{array}{l}\text { Chronic active hepatitis } \\
\text { Chronic nonspecific diarrhea } \\
\text { of infancy }\end{array}$ & $\begin{array}{l}58 \\
96\end{array}$ & $\begin{array}{l}8.1 \\
2.9\end{array}$ & $\begin{array}{l}91.9 \\
97.3\end{array}$ & $\begin{array}{l}0.087 \\
0.030\end{array}$ \\
\hline $\begin{array}{l}3 \\
4\end{array}$ & $\begin{array}{l}\text { Hepatic coma, postshunt } \\
\text { Type } 3 \text { glycogen storage dis- } \\
\text { ease }\end{array}$ & $\begin{array}{l}142 \\
484\end{array}$ & $\begin{array}{l}6.4 \\
3.5\end{array}$ & $\begin{array}{l}96.3 \\
96.5\end{array}$ & $\begin{array}{l}0.067 \\
0.036\end{array}$ \\
\hline $\begin{array}{l}5 \\
6\end{array}$ & $\begin{array}{l}\text { Rhabdomyalysis } \\
\text { Allergic reaction to constrast } \\
\text { material }\end{array}$ & $\begin{array}{l}994 \\
3206\end{array}$ & $\begin{array}{r}2.1 \\
13.3\end{array}$ & $\begin{array}{l}97.9 \\
86.7\end{array}$ & $\begin{array}{l}0.02 \\
0.15\end{array}$ \\
\hline $\begin{array}{r}7 \\
\text { Mean } \pm \text { S.D. }\end{array}$ & Fulminant hepatic necrosis & $\begin{array}{c}5087 \\
1438 \pm 1955 \\
\end{array}$ & $\begin{array}{c}2.8 \\
5.6 \pm 4.0 \\
\end{array}$ & $\begin{array}{c}97.2 \\
94.8 \pm 4.1 \\
\end{array}$ & $\begin{array}{c}0.029 \\
0.061 \pm 0.047\end{array}$ \\
\hline
\end{tabular}

${ }^{1}$ AST, aspartate aminotransferase.

of Reye's Syndrome was based on a typical history of prodromal illness followed by lethargy, persistent vomiting, and progressive stages of neurologic dysfunction (10). The characteristic elevations of serum AST, blood ammonia, and prothrombin time were present in each patient. Diffuse microvesicular steatosis of hepatocytes was observed in each of the seven patients in whom a liver biopsy was performed. Initial serum samples were drawn within $24 \mathrm{~h}$ of hospital admission in all cases and sequential samples were obtained in two patients.

As shown in Table 1, the group of patients with Reye's Syndrome encompasses a wide range of severity of disease and of serum AST concentrations. Mild disease is illustrated by patient 2 who progressed only to stage II and recovered without sequelae. In contrast, patient 10 progressed rapidly to stage $\mathrm{V}$ coma and brain death. AST elevations in this group ranged from $77.6-2414$ with a mean of 670 U/liter.

Patients with disorders associated with increased serum AST. This group consisted of individuals with a variety of diseases (see Table 2) causing moderate or marked elevations of total serum AST.

Subjects with serum AST in the normal range. This "normal" control group consisted of children and adults whose total serum AST values were in the normal range (20-40 U/liter).

Statistical methods. Study groups were compared using Student's unpaired, one-tailed $t$ test.

\section{RESULTS}

The \% of mitochondrial isoenzyme was significantly lower ( $P$ $<0.05)$ in the Reye's Syndrome group compared with the "normal" control group. This difference was not attributable to increased total AST activity in the Reye's Syndrome group, in view of the fact that the percent of mitochondrial isoenzyme was also significantly lower $(P<0.05)$ in the Reye's Syndrome group than in the "elevated" control group, which had an even higher mean serum AST.

Sequential samples were obtained in patients 2 and 10 at 1 and 4 days after the first sample, respectively. The measurements of the second sample are given in Table 1 in parentheses. No striking change in isoenzyme ratio was detected in the course of Reye's Syndrome in these patients. The total AST concentrations and percent of mitochondrial isoenzyme were similar in the subgroups of patients with varicella and with influenza-like prodromes.

\section{DISCUSSION}

The results of the present study indicate that the $\%$ of mitochondrial isoenzyme of AST is not increased in serum from patients with Reye's Syndrome; indeed, we detected a statistically significant decrease in comparison to both a group of control patients with normal total serum AST and in comparison to a 
group of control patients with increased total serum AST as the result of various liver disorders.

These results do not agree with those of a previous "preliminary" report. We have carefully considered potential sources of discrepancy and assert that it is unlikely that a significant increase in the mitochondrial fraction went undetected in the presently reported study. We found no evidence that the serum from Reye's Syndrome patients changes the binding characteristics of the DEAE A50 column, and column eluates rechromatographed appropriately. As reported by others (13), we found both isoenzymes to be stable under the conditions employed in this study. Serum samples obtained within $4 \mathrm{~h}$ of admission to the hospital and within 1 or 2 days of the onset of nausea gave no indication that a very early rise in the enzyme ratio had been missed. Sequential samples on two patients, after 1 and 4 days, respectively, gave no evidence of the decline reported in the previous study. Finally, the serum mitochondrial activity of our "normal" group expressed both in U/liter and as \% of total activity is similar to that found by several investigators using chromatography (26), immunoprecipitation (22), and immunoinhibition (22).

There is evidence that suggests an artifactual increase in the measured mitochondrial fraction in the previous study. The mean $\%$ of mitochondrial isoenzyme for the normal group in the previous report is $25 \%$, a value near the maximum that has ever been reported $(7,9,18)$ and higher than we detected in any individual in any group. This high mean $\%$ of mitochondrial activity for the normal group suggests that the chromatographic technique used in the previous study, a DEAE cellulose method (31), may have been at or beyond the point of saturating the binding sites for the cationic serum proteins. In our hands, DEAE cellulose proved an unsatisfactory resin for this reason. Failure to bind the cationic, cytosolic AST isoenzyme would cause an artifactual increase in the apparent mitochondrial contribution.

Mitochondrial injury has been proposed as a central pathogenetic mechanism in Reye's Syndrome based upon ultrastructural studies that have consistently found characteristic mitochondrial abnormalities in the hepatic tissue from these patients $(1,15)$. The structural abnormalities have been associated with reductions of several mitochondrial enzymes; however, some mitochondrial enzyme activities remain normal. Enzymes measured have included several from the urea cycle $(3,29,30,32,33)$, electron transport, oxidative metabolism, and glycolysis $(8,12$, 24,25 ). AST activities in mitochondria and cytosol from liver of patients with Reye's Syndrome have not been analyzed and compared with corresponding activities in human liver tissue from normal subjects. The demonstrated reduction of many mitochondrial enzymes raises the question whether the mitochondrial enzymes have been destroyed, synthesized at a greatly reduced rate, "leaked out" of an injured mitochondria, or a combination of these processes. If one assumes that the relative rates of removal of the isoenzymes from the serum are unchanged (this has not been measured), our finding of a reduced mitochondrial isoenzyme in the serum suggests that rate of release mitochondrial AST is decreased. If the mitochondrial content of AST is indeed reduced along with most other mitochondrial enzymes, we would infer that the reduction reflects destruction of the enzymes and/or reduced synthesis of the enzymes rather than an increased release rate from "leaky" mitochondria.

Our finding that the \% of mitochondrial isoenzyme is significantly lower in patients with Reye's Syndrome raises the question whether a low \% of mitochondrial activity could be used as a clinical marker of Reye's Syndrome. Although the mitochondrial AST of the Reye's patients as a group was significantly decreased, the value of only one of 10 patients with Reye's Syndrome was below the measured range of the "normal" control group; the value for only four of the 10 individuals with Reye's Syndrome was below the range of the "elevated" control group. This finding suggests that the \% of mitochondrial isoenzyme is not likely to be clinically useful in diagnosing or predicting progression to Reye's Syndrome.

\section{REFERENCES AND NOTES}

1. Bove, K. E., McAdams, A. J., Partin, J. C., Partin, J. S., Hug, G., and Schubert, W. K.: The hepatic lesion of Reye's syndrome. Gastroenterology, 69: 685 (1972).

2. Boyd, J. W.: The intracellular distribution, latency and electrophoretic mobility of L-glutamate-oxalacetate transaminase from rat liver. Biochem. J., 81: 434 (1961).

3. Brown T. Hug G., Lansky, L., Bove, K. E., Shere, A., Ryan, M., Brown, R. Schubert, W. K., Partin, J. C., and Lloyd-Still, J.: Transiently reduced activity of carbamyl phosphate synthetase and ornithine transcarbamylase in liver of children with Reye's syndrome. N. Engl. J. Med., 294: 861 (1976).

4. Bruns, D. E., Savory, J., Titheradge, A. C., Cross, R. E., and Wills, M. R.: Evaluation of the IFCC-recommended procedure for serum aspartate aminotransferase as modified for use with the centrifugal analyzer. Clin. Chem., 27 (1): 156 (1981).

5. Corey, L., Rubin, R. J., Hattwick, M. A. W., Noble, G. R., and Cassidy, E.: The 1974 nationwide outbreak of Reye's syndrome: its epidemiologic relationship to influenza B. Am. J. Med., 61: 615 (1976).

6. Decker, L. E. and Rau, E. M.: Multiple forms of glutamic-oxalacetic transaminase in tissues. Proc. Soc., Exper. Biol. Med., I12: 144 (1963).

7. Gabrieli, E. R. and Orfanos, A.: A clinical study of serum glutamic oxalacetic transaminase isoenzymes in liver diseases. Proc. Soc. Exp. Biol. Med., 128: 803 (1968).

8. Greene, H. L., Wilson, F. A., Gluck, A. D., Dunn, G. D., and Kilroy, A. W.: Hepatic ATP and glycolytic enzyme activities in Reye's syndrome. J. Pediatr. 89: 777 (1976).

9. Ideo, G., de Franchis, R., Bellobuono, A., and Tornaghi, G.: Aspartate aminotransferase isoenzymes in human serum in various liver diseases. Enzyme, 12: 529 (1971).

10. Lovejoy, F. H., Jr., Smith, A. L., Bresnan, M. J., Wood, J. N., Victor, D. I., and Adams, P. C.: Clinical staging in Reye syndrome. Am. J. Dis Child., 128: 36 (1974).

11. Martinez-Carrion, M. and Tiemeier, D.: Mitochondrial glutamate-aspartate transaminase. I. Structural comparison with the supernatant isozyme. Biochemistry, 6: 1715 (1967).

12. Mitchell, R. A., Michal, L. R., Edgardo, L. A., and Chung, H. C.: Comparison of cytosolic and mitochondrial hepatic enzyme alterations in Reye's syndrome. Pediatr. Res., 14: 1216 (1980).

13. Miyake, S.: The mechanism of the release of hepatic enzymes in various liver diseases. I. Alterations in cytoplasmic and mitochondrial enzyme activities in serum. Acta Med. Okayama, 33 (4): 287 (1979).

14. Moss, D. W. (chairman): Provisional recommendations on IFCC methods for the measurement of catalytic concentrations of enzymes, a special report. Clin. Cem., 24 (4): 720 (1978).

15. Partin, J. C., Schubert, W. K., and Partin, J. S.: Mitochondrial ultrastructure in Reye's syndrome (encephalopathy and fatty degeneration of the viscera). N. Engl. J. Med., 285: 1339 (1971).

16. Recommendations of the German Society for Clinical Chemistry: Standardization of methods for the estimation of enzyme activities in biological fluids: Experimental basis for the optimized standard conditions. Z. Klin. Chem. Klin. Biochem., $10(6): 281$ (1972).

17. Rej, R.: Isolation and characterization of the aspartate aminotransferase isoenzyme system from human liver. Ph.D. thesis (1976). Abstracted in Diss. Abstr. Int. 37, 1235B (1976).

18. Rej. R.: Aspartate aminotransferase activity and isoenzyme proportions in human liver tissues. Clin. Chem.. 24: 1971 (1978).

19. Rej. R.: Quantitation of aspartate aminotransferase isoenzymes by immunologic methods: Use of antibodies directed against the mitochondrial isoenzyme. Clin. Biochem., 12: 250 (1979).

20. Rej. R., Bretaudiere, J. P., and Graffunder, B.: Measurement of aspartate aminotransferase isoenzymes: six procedures compared. Clin. Chem., 27. 535 (1981).

21. Rej, R., Fasce, C. F., Jr., and Vanderlinde, R. E.: Increased aspartate aminotransferase activity of serum after in vitro supplementation with pyridoxal phosphate. Clin. Chem., 19: 92 (1973).

22. Rej, R. and Vanderlinde, R. E.: Effects of buffers on aspartate aminotransferase activity and association of the enzyme with pyridoxal phosphate. Clin. Chem.. $21(11): 1585$ (1975).

23. Rej, R., Vanderlinde, R. E., and Fasce. C. F., Jr.: An L-aspartate: 2-oxoglutarate aminotransferase reference material from human erythrocytes: preparation and characterization. Clin. Chem., 18 (4): 374 (1972).

24. Robinson, B. H., Gall, D. G., and Cutz, E.: Deficient activity of hepatic pyruvate dehydrogenase and pyruvate carboxylase in Reye's syndrome. Pediatr. Res., 11: 279 (1977).

25. Robinson, B. H., Taylor, J., Cutz. E., and Gall, D. G.: Reye's syndrome: preservation of mitochondrial enzymes in brain and muscle compared with liver. Pediatr. Res., 12: 1045 (1978).

26. Sampson, E. J.. Miller, S. A.. McKneally, S. S., Whitner, V. S., Hannon, W. $\mathrm{H}$. and Burtis, C. A.: Column-chromatographic separation of isoenzymes of aspartate aminotransferase. Clin. Chem., 24 (10): 1805 (1978)

27. Schmidt, E., Schmidt, F. W., and Otto, P.: Isoenzymes of malic dehydrogenase, glutamic-oxaloacetic transaminase and lactic dehydrogenase in diseases of the liver Clin. Chim. Acta, 15:283 (1967).

28. Shaywitz B. A. Rothstein, P., and Venes, J. L.: Monitoring and management of increased intracranial pressure in Reye syndrome: results in 29 children. Pediatrics, 66 (2): 198 (1980).

29. Sinatra, F. Yoshida, T., Applebaum, M., Mason, W., Hoogenraad, N. J., and Sunshine, P.: Abnormalities of carbamyl phosphate synthetase and ornithine 
transcarbamylase in liver of patients with Reye's syndrome. Pediatr. Res., 9: 829 (1975).

30. Snodgrass, P. J. and DeLong, G.: Urea cycle deficiencies and an increased nitrogen load producing hyperammonemia in Reye's syndrome. N. Engl. J.
Med., 294: 855 (1976).

31. Thaler, M. M. Personal communication.

32. Thaler, M. M.: Clinical and enzymatic indices of hepatic dysfunction in Reye's syndrome. In: John F. S. Crocker (Ed), Reye's syndrome II. pp. 115-137 (Grune \& Stratton, Inc., 1979).

33. Thaler, M. M., Hoogenraad, N. J., and Boswell, M.: Reye's syndrome due to a novel protein tolerant variant of ornithine-transcarbamylase deficiency. Lancet, 2: 438 (1974).
34. Requests for reprints should be addressed to: Dr. Donald M. Mock, Division of Gastroenterology and Nutrition, Department of Pediatrics, The University of Texas Health Science Center at San Antonio, 7703 Floyd Curl Drive, San Antonio. Texas 78284

35. Supported by the National Institutes of Health Grant \# HDO 3148 and grant RR-00079 from the Division of Research Resources, National Institutes of Health, General Clinical Research Center. During a portion of this work, Dr. Mock was the Clinical Associate Physician of the General Clinical Research Center.

36. Received for publication September 13, 1982.

37. Accepted for publication March 18, 1983.

\title{
Transcutaneous Bilirubinometry II. Dermal Bilirubin Kinetics during Phototherapy
}

\author{
THOMAS HEGYI, ${ }^{(20)}$ I. MARK HIATT, IAN M. GERTNER, ROBERT ZANNI, AND
} THEORODORE TOLENTINO

Division of Neonatology, Department of Pediatrics, UMDNJ-Rutgers Medical School, and the Divisions of Neonatology, Monmouth Medical Center and St. Peter's Medicial Center, New Brunswick, New Jersey, USA

\begin{abstract}
Summary
We examined the effect of phototherapy on cutaneous bilirubin using the transcutaneous bilirubinometer (TcB) in 14 white infants at a mean postnatal age of $30 \mathrm{~h}$. Six infants were treated with blue light, eight with white light. An opaque patch, $2.5 \mathrm{~cm}$ in diameter, covered the skin and served as a source for TcB control values. Simultaneous TcB measurements were obtained from exposed and patched areas every $15 \mathrm{~min}$ during $4 \mathrm{~h}$ of phototherapy.

After the start of phototherapy, TcB index obtained from patched skin did not change during the course of treatment. Data from exposed skin showed that the initial rate of TcB index fall during the first hour was significantly faster than the successive values during the next $3 \mathrm{~h}$ in both groups studied. During the first $2 \mathrm{~h}$ of therapy the TcB index decreased faster among infants treated with blue light.

Correlation studies indicate that TcB measurements from exposed skin areas may not be clinically useful in predicting serum bilirubin response to phototherapy but data obtained from unexposed sites may fill this role.

Previous studies have shown that visible light significantly reduces serum bilirubin concentrations in infants $(7,10)$. The photochemical reactions responsible for this effect, photodegradation and photoisomerization, occur primarily in exposed skin $(6,12)$. Shaded sites remain icteric and exposed areas are bleached under phototherapy (1).

In the present work the TcB (19) was used to monitor the responses of cutaneous bilirubin to phototherapy. The experiments were undertaken to determine the rate and the extent of skin decolorization and through direct skin measurements to help explain the model of action of phototherapy. This protocol was approved by the Institutional Committee on Research.
\end{abstract}

\section{MATERIALS AND METHODS}

Fourteen infants were studied. Birthweight ranged from 660 $3200 \mathrm{~g}$, gestation age from $26-41 \mathrm{wk}$, and postnatal age from 4 $63 \mathrm{~h}$. Patients were selected for study if they met the following criteria: (1) requirement for phototherapy to treat hyperbilirubinemia; (2) ability to maintain infant in a supine position for 4 $\mathrm{h}$; (3) availability of personnel to attend patient for $4 \mathrm{~h}$; and (4) ability to obtain consent form from mother or legal guardian. Infants with hemolytic anemia, positive Coombs test, or severe respiratory problems were excluded.

The infants were divided into two groups based on the type of phototherapy used. Group I was treated with blue light and Group II with white light. There were six infants in Group I, all nursed naked in incubators (Isolette, Air Shields, Hatboro PA). Eight special blue fluorescent lamps (Westinghouse, F-20T 12) $\mathrm{BB}$ ) were encased in a standard nursery phototherapy module and positioned above the incubators. Group II consisted of eight infants nursed naked on radiant warmer beds (Infant Care Systems, Air Shields Co.) and treated with fluorescent bulbs housed in the phototherapy attachment (Air Shields, 78-800-70) of the warmer bed. Irradiance at the infant's level was measured with a photometer (Air Shields, Model PR-111). Radiant flux in the $425-475 \mathrm{~nm}$ band was $11.6 \pm 1.5 \mu \mathrm{W} \cdot \mathrm{cm}^{-2} \cdot \mathrm{nm}^{-1}$ (mean \pm S.D.) in Group I and $5.2 \pm 0.8 \mu \mathrm{W} \cdot \mathrm{cm}^{-2} \cdot \mathrm{nm}^{-1}$ in Group II. The difference between irradiances was significant at the $P<0.001$ level.

TcB index was measured on the exposed sternal area every 15 min during $4 \mathrm{~h}$ of phototherapy. Simultaneous measurements were obtained from a nearby site covered by an opaque patch $2.5 \mathrm{~cm}$ in diameter. The TcB's (Minolta, Japan) operating principles have been described previously (19). This spectral reflectometer measures the color intensity of the skin and provides a numerical TcB index that has been correlated to serum bilirubin concentrations $(5,19)$. 